Marine Research in Indonesia No. 18, $1977: 23-57$.

\title{
THE MANGROVE FORESTS OF CAIRNS, NORTHERN AUSTRALIA
}

\author{
by
}

\author{
E.J. HEGERL ${ }^{1}$ ) and J.D.S. DAVIE ${ }^{2)}$
}

ABstract

Surveys of the flora and fauna of the Cairns tidal wetlands were carried out by members of the Australian Littoral Society during the summers of 1974 and 1975. These wetlands cover an area of 6000 hectares in Trinity Inlet and the Barron River delta.

The Cairns mangrove and saltmarsh vegetation forms distinct patterns of zonation which appear to be largely controlled by the volume and constancy of freshwater flow.

The results of extensive collections revealed a wetlands associated fauna of invertebrates and fish that is considerably more diverse than has previously been reported for northern Queensland. While some species are ubiquitous, many of the invertebrates have been found only in a discrete habitat within particular zones of vegetation. Species diversity of molluscs and crustaceans is greatest in the most constantly inundated zones. A diverse fauna occurs in rotted mangrove logs.

Data were obtained on the export of organic material from a small mangrove watershed on one day in December 1975. These revealed a figure for detritus of $11.3 \mathrm{gC} / \mathrm{m}^{2} /$ day. This was composed of a 'dissolved' organic carbon fraction of $6.3 \mathrm{gC} / \mathrm{m}^{2} /$ day, and $5.0 \mathrm{gC} / \mathrm{m}^{2} /$ day of particulate organic carbon. These figures are discussed in relation to available literature on mangrove forests and estuaries.

Rapid urban and agricultural development of Cairns is now placing a large portion of these wetlands under serious threat of destruction. The prospects for the future conservation of the Cairns tidal wetlands are discussed.

\section{INTRODUCTION}

The Australian Littoral Society has been collecting basic data on the composition and distribution of mangrove fauna and flora along the east coast of Australia since 1968. Until recent years these surveys focused attention upon the extensive sub-tropical wetlands areas of Moreton Bay and Hervey Bay in southern Queensland. The data collected from these areas provided material for the compilation of the first comprehensive keys to the wetland biota of the region (MORRIS 1971). This work provided a tool, and inspiration to carry these studies farther afield. A subsequent appreciation of the high regional variation in the biota of wetland areas, and the pressure of increasing exploitation of these valuable resources has since taken Society field workers into estuaries from Cape York in north Queensland to Westernport Bay in Victoria. Figure 1 illustrates the estuaries and bays which have received some detailed attention.

1) Australian Littoral Society, P.O. Box 82, St. Lucia, Q 4067, Australia.

2) School of Australian Environmental Studies, Griffith University, Nathan, 0 4111, Australia. 


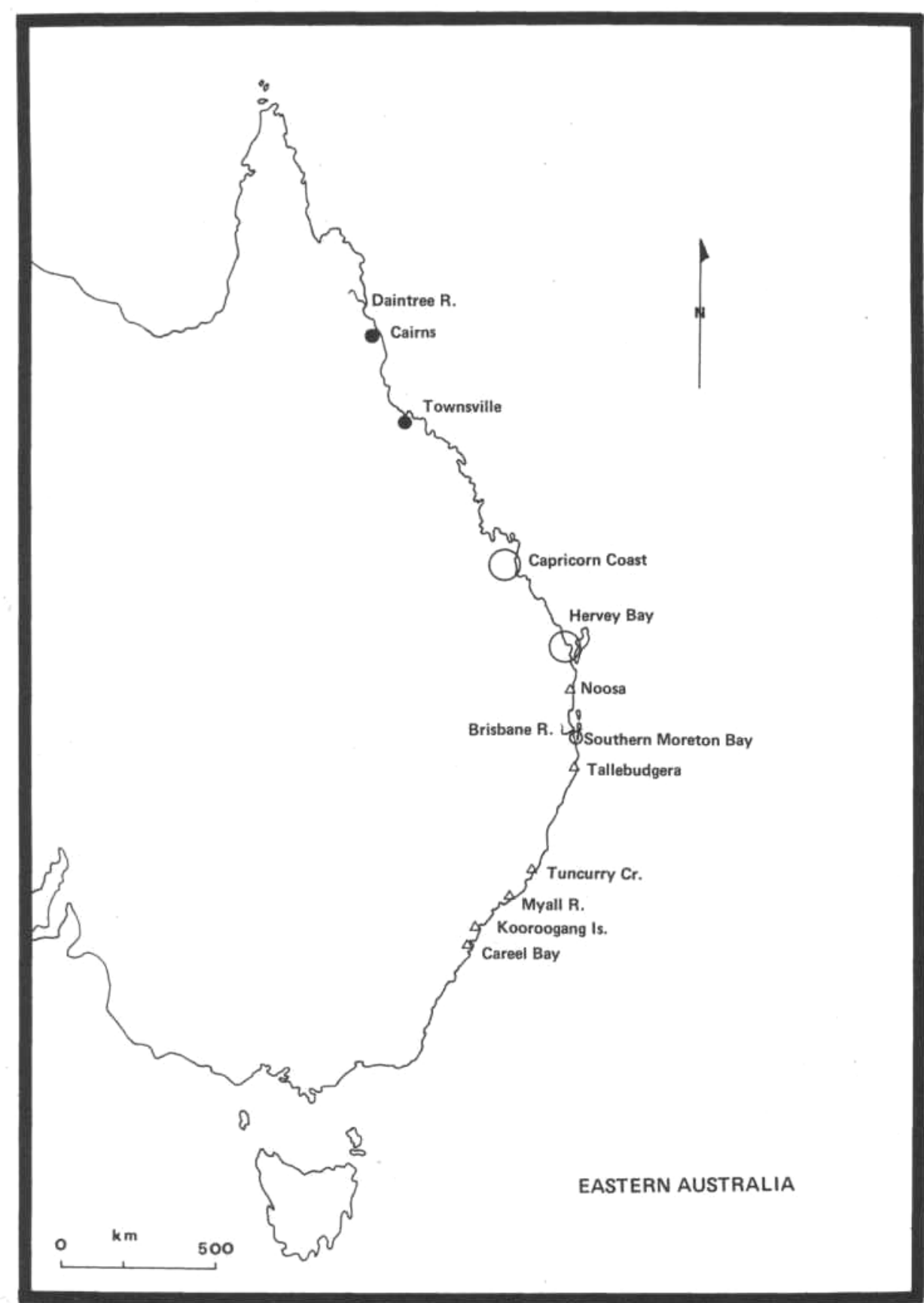

Figure 1 Locality map showing sites of estuaries which have been surveyed by the Australian Littoral Society. 


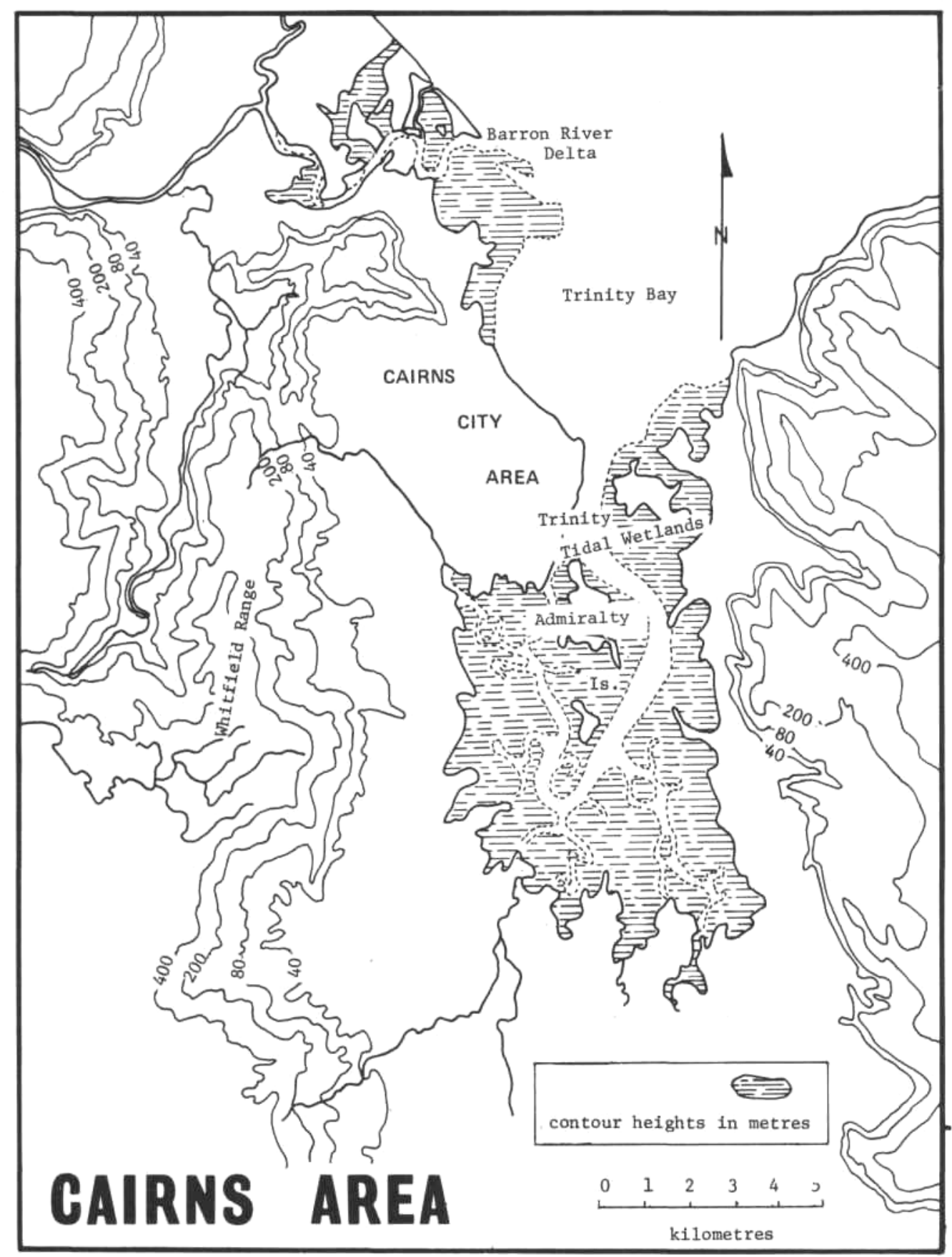

Figure 2. Map illustrating extent and relative positions of the Cairns wetland areas. 
Cairns is a coastal city situated between longitudes $145^{\circ} 45^{\prime}$ and $145^{\circ}$ $49^{\prime}$ East and latitudes $16^{\circ} 5^{\prime}$ and $17^{\circ} 1^{\prime}$ South. It is fringed to the north and the south by over 6000 ha. of mangrove forest and saltmarsh (Fig. 2). Of this about 5000 ha. lies to the south of the city in Trinity Inlet with the remainder occurring to the city's north in the delta of the Barron River. These two areas of mangrove forest were once contiguous, but are now separated following the development of the city of Cairns. This paper reports upon the results of field surveys of the flora and fauna of these two wetland areas carried out by members of the Australian Littoral Society during the month of December in 1974 and in 1975. The study involved 890 man hours of actual field work. Most of this was concentrated in Trinity Inlet. However, sufficient work was directed towards the Barron River to allow some interesting comparisons in the distribution of the dominant mangrove species. Results of the 1974 survey have been documented by GRAHAM et al. (1975). MiLlER (1976) has presented data on the export of organic matter from the Trinity Inlet wetlands from measurements carried out during the 1975 study.

\section{HISTORY AND GEOMORPHOLOGY}

Trinity Inlet lies at the northern end of a lowland morphological and structural corridor which runs south to Innisfail. It is flanked to the west by the Whitfield Range rising above 1000 metres, and underlain by metasediments of the Barron River metamorphics. To the east, Permian Mareeba Granite intrudes the metamorphics and exhumed pluton form peaks rising above 1000 metres.

The Inlet once formed the estuary of the Mulgrave River which now flows into the sea $35 \mathrm{kms}$ to the south at Russell Heads. This diversion resulted from volcanic activity in the Pleistocene which raised the land surface near Gordonvale. Subsequent history has involved sea level fluctuations and the seaward development by sedimentation and mangrove colonisation of the area now occupied by the city of Cairns. Ancient shorelines form a distinctive succession of concentric arcuate dunes which may be seen undisturbed on Admiralty Island (BIRD 1970).

Continuing sedimentation from the Barron River is building extensive mudbanks into Cairns Bay and the inshore margins are being rapidly colonised by a distinctive Avicennia zone. Only continual 'weeding' of mangrove seedlings by the local authority preserves the present location of the foreshore. 
In general the substrate of the more frequently inundated mangrove zones is deep soft mud. In the less frequently inundated zones it is generally a firm clay. Along the streams draining the eastern granites there is a significant proportion of coarse granite sand and gravel composed predominantly of quartz and feldspar.

\section{RAINFALL AND HYDROLOGY}

In the course of a normal year there is characteristically three climatic regimes operating. The area is subject to tropical monsoonal influences from January to April; from May to September the weather tends to be cooler and dryer; and from October to December is hot and dry. The mean annual rainfall is about $2000 \mathrm{~mm}$ but this has fluctuated between a maximum of $4434 \mathrm{~mm}$ and a minimum of $1119 \mathrm{~mm}$.

Since the diversion of the Mulgrave River the catchment of Trinity Inlet has been restricted to over twenty small streams with very steep headwater gradients. Low run-off conditions prevail during the dry season from May to December; but heavy run-off occurs during the wet season from December to April, when half a metre of rain may fall in two to three days. Coupled with the large tidal fluctuations (3.2 m maximum spring tidal range) and the deep, narrow channels into the mangroves, high salinity conditions are maintained even in the upper reaches of the Inlet for most of the year.

The Barron River on the other hand drains a catchment of more than 200,000 ha. including high rainfall areas of mountainous rainforest. Thus the Barron River delta is influenced by a larger, and somewhat more constant, flow of freshwater from its catchment than is Trinity Inlet. We feel these differences in the pattern of freshwater flow are of considerable importance in interpreting the differences in the structure and composition of the mangrove flora between the two study areas. This is supported by the findings of REARK \& TEAS (1976) who have described mangrove responses to a change in freshwater drainage from the Florida Everglades. It is in agreement with other observations we have made in southern Moreton Bay (unpublished data, Australian LiTTORAL SOCIETY ), where the patterns of freshwater run-off have been altered by human interference.

\section{SURVEY METHODS}

The field methods adopted in Australian Littoral Society surveys have been described in MORRIS (1971). In summary, the objectives of these sur- 


\section{E.J. HEGERL \& J.D.S. DAVIE}

veys are to provide information on biogeographic distribution; to describe details of macro and micro habitat features; to determine species richness; to identify species of local or scientific interest; to obtain records which will be of historical significance; and to provide data which may subsequently be analysed to elucidate synecological interrelationships. To achieve these objectives the survey consists of three parts :

(1) description of area and location of sites;

(2) preparation of check lists;

(3) habitat and species association study.

In this respect the survey method follows a descending multilevel approach. Study sites within the mangroves are chosen after examination of colour, and black and white aerial photographs and the preparation of field maps. This is followed by an extensive reconnaissance in the field by boat and on foot. The object of this reconnaissance is to clearly identify and plot representative plant communities. The sites selected by this process tend to be spread through a range of pure and mixed species stands across the intertidal gradient and along the salinity gradient of the estuary. After the collection of this information, survey teams move into the study areas on foot and species and habitat data are collected, coded and recorded on pro forma report sheets. These pro formas are contained in Appendix A. In the Cairns wetlands 54 mangrove and saltmarsh sites have been studied in this way. Forty-seven of these sites were located in Trinity Inlet.

\section{MANGROVE ZONATION IN TRINITY INLET}

Figure 3 is a profile diagram of the typical pattern of distribution of dominant canopy species across the intertidal zone in Trinity Inlet. It is estimated that at least $80 \%$ of the mangrove vegetation fringing the shores of Trinity Inlet consists of Rhizophora stylosa. The dense zone formed by this species is sometimes homogeneous, or it may be mixed with $R$. apiculata. In some areas $R$. apiculata forms homogeneous or nearly homogeneous stands.

At a very limited number of points scattered about the Inlet and the creeks leading into the Inlet, individual trees or clumps of Sonneratia alba occur at a lower tidal level than the Rhizophora. Individual trees of Avicennia marina ${ }^{3)}$ are occasionally found on the outer edge of the Rhizophora zone. However, outside the Inlet along the shores of Trinity Bay, Avicennia

3) A. marina is considered synonomyous with A. eucalypti folia in this paper. This is in agreement with our observations of extreme ecotypic variability within this species and is supported by MACNAE (1968). 


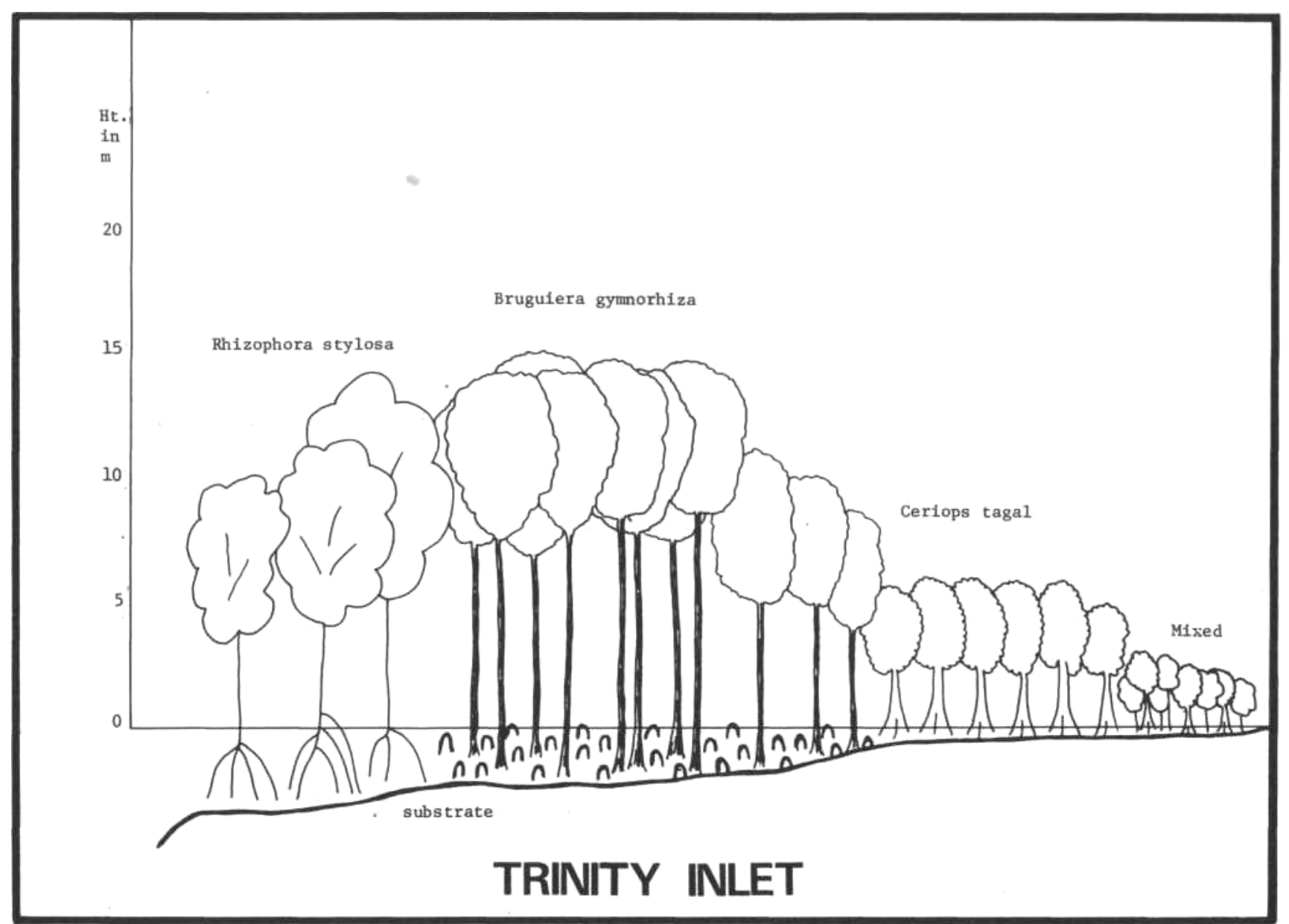

Figure 3 . Profile diagram of the mangrove vegetation across the intertidal in Trinity Inlet. 


\section{EJ. HEGERL \& J.D.S. DAVIE}

forms a zone that is advancing far out on to the mud flats. These Avicennia vary from seedling size to about 5 metres in height where they merge with the Rhizophora zone.

Both inside the Inlet and along the shores of Trinity Bay the Rhizophora zone tends to be 10 to 12 metres in height along its outermost edge. The canopy of the Rhizophora forest rises to a maximum of 15 to 20 metres and then merges with a zone of Bruguiera gymnorhiza, usually at least of comparable height. This zone is often homogeneous, although there may be scattered Rhizophora present. The canopy height of the Bruguiera zone then decreases rapidly where it joins the less frequently inundated Ceriops tagal zone.

Homogeneous stands of C. tagal are common, but the zone may also include scattered Rhizophora stylosa and Bruguiera gymnorhiza. Where the canopy is low and broken, Osbornia octodonta may be present. In some areas the Ceriops zone borders directly on Melaleuca or Eucalyptus forest. In others it is backed by a saltmarsh, or by a landward fringe zone containing 2 to 5 metre high Avicennia, or by a mixture of species. When the latter situation occurs, any of the mangrove species recorded in the Inlet may be present, other than Sonneratia alba. This mixed landward fringe zone is inundated only by the high spring tides. Of the 20 species that are found here, Rhizophora stylosa and Bruguiera paruiflora are the least common.

In addition to these more frequently occurring assemblages, GRAHAM et al. (1975) describe an "upstream fringe zone". This zone appears to be a consistent variant of the landward zones described above in that it occupies the region inundated only on the higher spring tides. However, it is encountered only in the upper regions of the small mangrove creeks where the substrate is a firm clay. In the areas examined, the zone is seldom more than 20 metres wide and grades into typically terrestrial or freshwater stream-fringing vegetation.

In structure the zone bears some resemblance to the Bruguiera gymnorhiza association described by DE HAAN (1931) at Tjilatjap in southern Java. At one of the sites studied the vegetation is a mixture of $10-15 \mathrm{~m}$ high B. gymnorhiza, B. exaristata, Xylocarpus granatum and Excoecaria agallocha. There is a dense understory of Acanthus ilicifolius 1.3 metres high and scattered individuals of the lily Crinum pedunculatum up to 1.5 metres high. Areas nearby contain an understory of Acrostichum speciosum less than a metre in height with thickets of 2 to 3 metre high Aegiceras corniculatum fringing the creek. In other areas Heritiera littoralis are abundant and some mixed stands also containing B. gymnorhiza, X. granatum and E. agallocha reach heights of 15 metres. Scattered Cynometra ramiflora are found on the inner margins of these upstream areas. 


\section{MANGROVE ZONATION IN THE BARRON RIVER DELTA}

The distribution patterns of mangrove species in the Barron River delta are more complex and variable than those encountered in Trinity Inlet. The observations which follow are derived from the study of only 7 sites in the Barron River delta, and it is probable that further variation is present. Sufficient data are available, however, to indicate that there are significant differences between the zonation patterns which occur in these 2 areas.

Avicennia marina again occur at the lowest tidal level on soft mud along the seaward fringe. However, in one such area, shrubs of Aegialitis annulata also occur at this same tidal level. In contrast to Trinity Inlet, Avicennia marina forms a distinct channel-fringing zone in low-lying areas within the estuary. Further upstream this species forms a zone immediately behind dense stands of river-fringing Aegiceras corniculatum.

Bruguiera parviflora forms a well-developed zone in the estuary which wholly, or partially, replaces the B. gymnorhiza zone of Trinity Inlet. In the Barron delta study sites the zone which backs on to the B. parviflora is dominated by Ceriops decandra, rather than $C$. tagal, the dominant of the Ceriops zone in Trinity Inlet.

The Ceriops zone in the Barron River delta may also contain a variety of other species. In some areas Xylocarpus australasicum is common amongst the C. decandra. Ceriops tagal, B. gymnorhiza, B. parviflora and X. granatum may also be present in smaller numbers. Heritiera littoralis and Excoecaria agallocha commonly form a narrow band along the inner margin of this zone.

\section{FAUNA OF MANGROVE FOREST ENVIRONMENT}

Our surveys have involved as many as twenty workers in the field at one time. This facility has provided the opportunity to collect detailed biological information from an environment that is often difficult to work in effectively. In order to obtain representative collections, it has been found necessary to work at all stages of the tide, day and night.

Table I is a summary of the species richness of the Cairns wetlands ${ }^{4}$, which is more fully documented in Appendix B. This list is not yet exhaustive. Indeed, our knowledge of some of the faunal groups, particularly the molluscs and the fishes, will be significantly increased when the analysis 
of the 1975 collections is completed. Polychaetes have also been collected, but not yet identified. However, the data which has been presented does indicate that a much higher diversity of organisms may live in these environments than has previously been recorded in the literature (e.g. MACNAE 1966, 1968). This is not surprising when it ijs considered that tropical mangrove forests offer a heterogeneous mosaic of microhabitats, in what is essentially a warm, humid, closed forest.

Table I. A summary of species richness in the cairns tidal wetlands

FLORA

Mangroves (13 Families) : 21 spp.

Mangrove Epiphytes:

Fungi ( $2^{+}$Families) : $14^{+}$spp. (part 1975 only)

Lichens ( $8^{+}$Families) : $14^{+}$spp. (1974 only)

Pteridophyta (1 Family) : 3 spp.

Magnoliatae (2 Families) : 2 spp.

Liliatae (Orchidaceae) : 5 spp.

Associated Wetlands Flora :

Pteridophyta (1 Family) : 1 sp.

Magnoliatae (5 Families) : 10 spp.

FAUNA

Liliatae (5 Families) : 8 spp.

Mollusca (26 $6^{+}$Families) : $54^{+}$spp. (1974 only)

Crustacea (21 Families) : 75 spp.

Insecta (19+ Families) : 30 spp. (1975 only)

Arachnida (14 Families) : 42 spp.

Pisces ( $32^{+}$Families) : $52^{+}$spp. (1974 only)

Reptilia (3 Families) : 3 spp.

GRAHAM et al. (1975) have tabulated microhabitat details for 108 species of molluscs and crustaceans collected from the Cairns wetlands. Of these, 34 species have been found as log infauna. These invertebrates and some small fish often utilize the tunnels and cavities created by the wood-boring teredid molluscs, which are a major agent in the decomposition process.

An additional 10 molluscs and crustaceans have been found to utilize this internal matrix of the decomposing logs either facultatively, or as a refuge for periods determined by external environmental conditions. For example, Ellobium aurisjudae is active on muddy substrates in the Rhizophora and Bruguiera zones only at night or on cloudy, rainy days. At other times it occurs as a part of the log infauna. Whether the insides of rotted logs may therefore be regarded as refuges from the physiological rigours of the external environment is not yet clear. However, it does seem that the recognition of these microhabitats could add a new dimension of complexity to the concept of faunal zonation in these environments. 
Our studies of the Cairns wetlands have revealed significant differences in the composition of the log fauna at different heights across the intertidal. Certain species, such as the gastropod mollusc, Pythia scarabeus, appear to be restricted to the Ceriops and landward fringe zones at the upper end of the intertidal, while other species, such as the Crustaceans Pachycheles sp. and Myomenippe fornasinii, have been found only in the most frequently inundated Rhizophora areas.

Within any one zone there is substantial variation from log to log in the composition of the log fauna. This suggests that an explanation of this distribution based only upon a gradient of inundation is unlikely to cope with the major source of variation in the log fauna of the mangroves as a whole. Indeed our observations indicate that any or all of the following factors are important :

(a) the agents of decomposition, as teredid borers will create quite different microhabitat conditions than fungi or isopod crus taceans;

(b) the state of decomposition due to the time the log has been present in the area;

(c) the orientation of the log, if it is standing, or caught upright, or lying on or partly buried in the substrate;

(d) the diameter and size of the log;

(e) the species from which the log is derived;

It is nevertheless clear that the physical environmental factors of frequency of inundation and salinity exert major influences on the composition and distribution of the fauna of mangrove forests. In Cairns, faunal groups which have aquatic affinities, such as molluscs and crustaceans, reach their greatest diversity in the frequently inundated Rhizophora and Bruguiera zones. Terrestrial groups such as the arachnids are most diverse in the infrequently inundated Ceriops and landward fringe zones. The highest diversity of molluscs (18 species) and crustaceans (14 species) were found in a 20 metre square site in the Rhizophora, at the southern end of Admiralty Island. The highest diversity of spiders was 9 species from a 20 metre square 'upstream fringe' zone site.

\section{MANGROVE AND THE PRODUCTIVITY OF ESTUARIES}

It has become fairly widely accepted that mangroves are very important to the productivity of estuaries. Despite the implications of this state- 
ment, very few comprehensive studies have been initiated to produce supportive data. The best information for an area derives from the pioneering work of HEALD (1971) and ODUM (1971) in the Rhizophora mangle forests of Florida. Data from tropical areas appear to be limited to the studies of Golley et al (1962) in Puerto Rico and Golley (1968) in Panama. However, ODUM \& HEALD (1975) now regard some of the Puerto Rican data as an underestimate of the expected annual production from this area. No comprehensive data are yet available for Indo-Pacific tropical mangrove forests.

During December 1975 information was collected on the net export of organic carbon as part of the Cairns wetlands study (MILLER 1976). Water samples were collected between an ebb and flood tide in one small tidal creek in Trinity Inlet. This creek drained an entirely mangrove catchment of 34 ha. on Admiralty Island (Fig. 2). The vegetation in this area was dominated by zones of Rhizophora stylosa, Bruguiera gymnorniza and Ceriops tagal. By assuming an equivalent export of carbon over the following tidal ebb and flood, these data were used to derive a daily primary productivity rate for the catchment. The results obtained indicate a total organic carbon production of $11.3 \mathrm{gC} / \mathrm{m}^{2} /$ day. This was comprised of particulate organic carbon amounting to $5.0 \mathrm{gC} / \mathrm{m}^{2} /$ day and 'dissolved' organic cabon $^{5)}$ of 6.3 . gC/m²/day. This estimate did not take into account floating leaves, fruit and twigs.

These figures are high in comparison to those reported by GOLLEY et al (1962) from Puerto Rico (1.1 gC/m²/day) and HEALD (1971) from Florida $\left(1.2 \mathrm{gC} / \mathrm{m}^{2} / \mathrm{day}\right)^{6}$. MiLLER (1976) has discussed methodological and ecological factors which help to rationalise our results in terms of these other comparative figures. However, it is to be expected that detrital export will vary widely. It is our view that the sources of variation have local, regional and larger geographical derivatives.

The sources of probable variation can be summarised by the following hypotheses, which we believe may be applicable to east Australian mangroves.

(a) The nutrient contribution to the estuary from mangrove vege tation will be related to the canopy height and the biomass of the vegetation.

(b) Rhizophora spp. and Bruguiera spp. which occur in the frequently

5) The dissolved organic carbon data were obtained from water samples passed through GF/C filter papers of 1-2 u mesh.

6) Assuming a 50\% conversion factor for the original data expressed as dry weight. 
inundated zones, where the available nutrients are high, will produce a higher turnover of vegetable material and be less conservative of their nutrients than the Ceriops spp. and other species which grow in infrequently inundated zones.

(c) The total nutrient contribution made by the mangrove forest to the estuary will be governed by the relative proportion occu pied by the different species in the assemblage.

(d) The biological and physiognomic features of the catchment, because of their effect on the quality and quantity of the surface and ground water reaching the estuary, will have a significant effect on the dynamics of the mangrove forest. Features such as the size of the catchment, the nutrient status of the soils, the nature of the catchment vegetation, and the nature of human activity will be important elements.

(e) The productivity of individual mangrove species and their contribution to the productivity of the estuary will be governed by their specific set of environmental and climatic optima.

As yet there are no data available with which to test any of these hypotheses. ODUM \& HEALD (1975) have stated that "there seems to be a similar leaf standing crop and production in mangrove forests, whether they are 5 or $40 \mathrm{~m}$ in height". However, this does not appear to be the case for most of the Australian species.

The present paucity of data on the importance of mangroves and saltmarshes to Australian estuaries is disturbing in view of the rate and magnitude of destruction of these areas, particularly in the wet tropical areas of north Queensland.

\section{CONSERVATION PROBLEMS}

While mangroves are widely distributed along the shorelines of Australia, the tallest and best developed forests occur in the wet tropical region of north-eastern Queensland along less than $450 \mathrm{~km}$ of coast. Much of this resource is still in a relatively pristine condition.

The Trinity Inlet and Barron River tidal wetlands are the most accessible for scientific research in Australia's wet tropical region. The great variety in patterns of floral and faunal distribution in such a small area also adds considerable scientific interest. In addition the Trinity Bay mud flats are regarded as an important stopover point for migratory birds from Asia. 
Trinity Inlet offers over $100 \mathrm{~km}$ of sheltered waterways for fishing and boating activities. Recreational use of the Inlet is already extensive. If present trends continue, the number of pleasure craft using the Inlet should expand more rapidly than the human population of the area. Fishing and boating trips around the Inlet also are becoming popular with tourists.

Unfortunately, just at a time when these values of the Cairns wetlands are beginning to be realized, other uses for wetlands are being developed by commercial interests. Air-photo analysis indicates that this has resulted in the destruction of about one quarter of Trinity Inlet's mangrove forests and saltmarshes in less than a decade.

The rapid destruction of such extensive areas is related to two important factors. The first of these, expansion of the sugar industry, has resulted in the destruction of almost $20 \%$ of Trinity Inlet's tidal wetlands. These areas have been reclaimed in the hope that they will prove economically viable for growing sugar cane. In cases where there is gross interference with drainage patterns the damage that results from constructing bunds across tidal wetlands and creeks can extend to adjoining areas. For example, in one locality in Trinity Inlet where a waterway immediately upstream had been dammed, there was almost a $100 \%$ mortality over an homogeneous 18 ha. stand of 10 - $12 \mathrm{~m}$ high Rhizophora stylosa forest. These trees were still being tidally inundated but had been deprived of freshwater flow from the stream they bordered. The only surviving trees occurred in a small patch adjacent to a floodgate which carried the overflow of heavy rains from the area. It is uncertain whether efforts to reclaim tidal wetlands for sugar cane production will continue, as salinity problems are proving difficult to overcome. The other factor which has been responsible for wetlands destruction in Trinity Inlet relates to the rapid population growth of the Cairns area. The city has almost reached the limits to growth imposed on it by its geographic position. .For a city surrounded by steep mountains, sugar cane fields and mangroves and mudflats, land-use conflicts can be expected to mount as unused land becomes increasingly scarce. Wetlands on both sides of the city have been destroyed to create additional wharf facilities, airport runways, industrial and residential land, and rubbish dump sites. Small areas have even been destroyed to provide boat jetties so that people can go fishing in the mangrove channels.

It should be possible to slow the rate of destruction of tidal wetlands in the Cairns area by better planning and use of resources, and by a better public understanding of the disadvantages to the community of continued wetlands destruction. A comprehensive land use study is needed to provide the people of the Cairns area with guidelines on the best possible use of 
resources and the optimum population which the area can support. If the people of Cairns wish to live in an attractive setting and depend largely on a tourism-based economy, they may have to limit the size of their city or opt for growth corridors or alternative growth centres in sugar cane lands beyond the city.

\section{CONCLUSIONS}

This study has added significantly to our appreciation of the complexity of tropical tidal wetlands environments. It has also thrown doubts on a number of generalities that have previously been accepted by many marine scientists. As a result of this project we do not believe that mangrove forests should continue to be thought of as places of low faunal diversity, or that the distribution of fauna within the forest should be attributed solely to variations in salinity, substratum or frequency of inundation.

A number of hypotheses also have been advanced to suggest that there may be considerable variation in production of organic detritus from east Australian mangrove forests. The fact that there is presently no data available with which to test these hypotheses emphasises the need for researchers to direct attention to this problem. The mangrove forests of the Cairns area are being rapidly destroyed for reasons that generally do not appear to be in the long term public interest. We believe that most of the remaining Cairns mangrove forests and saltmarshes should be reserved to protect their scientific and recreational value to Australia.

\section{ACKNOWLEDGEMENTS}

The authors are indebted to the very large number of individuals who made this project possible. The study was funded by the Australian Littoral Society, the Cape York Conservation Council and the Cairns Branch of the Wildlife Preservation Society of Queensland (W.P.S.Q.). Field work and most of the identification of specimens was carried out by members of the Australian Littoral Society. They were assisted logistically and in the field by the Cairns Branch W.P.S.Q., and the Cairns Sport Fishing Club. Dr. W. Ponder and Mr. P. Coleman of the Australian Museum identified certain species of molluscs, and Mr. P. DAVIE and Mr. R. MunRo of the Queensland Museum identified certain species of crustaceans. Staff of the Queensland Herbarium identified a number of plant specimens, and all of the fungi were identified by staff of the Queensland Forestry Department. Ms. JAN MC NALTY drew the diagrams, and the manuscript was typed by Ms. DiANE TARTE. 


\section{E.J. HEGERL \& J.D.S. DAVIE}

\section{REFERENCES}

BIRD, E.C.F. 1970. Coastal evolution in the Cairns district. The Aust. Geogr. 11(3) : 327 -335.

HAAN, J.H. DE 1931. Het een en ander over de tijlatjapsche vloedbosschen. Tectona 24 : 39 - 76 (English summary)

GOLLEY, F.B. 1968. Mineral Cycling in Tropical Forest Ecosystems. Unpublished manuscript from the Institute of Ecology. Cited In : ODUM, W.E. and E.J. HEALD 1975. Mangrove Forests and Aquatic Productivity.

GOLLEY, F.B., H.T. ODUM and R.F. WILSON 1962. The Structure and Metabolism of a Puerto Rican Red Mangrove Forest in May. Ecology 43(1): 9 - 19.

Graham, M., J. Grimshaw, E. Hegerl, J. McNalty and R. Timmins 1975. Cairns Wetlands: A Preliminary Report. Operculum 4(3/4): 117 - 148.

HEALD, H.J. 1971. The Production of Organic Detritus in a South Florida Estuary. Sea Grant Tech. Bull. No. 6. University of Miami, $110 \mathrm{pp}$.

MACNAE, W. 1966. Mangroves in Eastern and Southern Australia. Aust. J. Bot. 14: .67 - 104. 1968. A General Account of the Fauna and Flora of Mangrove Swamps and Forests in the Indo-West-Pacific Region. Adv. Mar. Biol. 6 : 73 - 270.

MILLER, G.J. 1976. Export and Production of Organic Detritus from North Queensland Mangroves on a Summers Day. Operculum 5(2): 56 - 60.

MORRIS, D. (Ed.) 1971. Field Manual for Tidal Swamps: Sub-Tropical Eastern Australia. Publication of the Australia Littoral Society, Brisbane.

ODUM, W.E. 1971. Pathways of Energy Flow in a South Florida Estuary. Sea Grant Tech. Bull. No. 7. University of Miami, $162 \mathrm{pp}$.

ODUM, W.E. and E.J. HEALD 1975. Mangrove Forests and Aquatic Productivity. In : HASLER, A.D. (Ed.) 1975. Coupling of Land and Water Systems. Springer-Verlag Berlin : 129-139.

REARK, J.B. and H.J. TEAS 1976. Some Effects of Land and Water Management on Tidal Forests of Lower Penninsula Florida, U.S.A. Paper presented to International Symposium on the Ecology and Management of Some Tropical Shallow Water Communities, Jakarta 1976. 


\author{
APPENDIX A \\ Explanatory Notes for the Use \\ of Field Sheet A: Macrohabitat Description
}

\title{
SITE IDENTIFICATION
}

The coding of items 1 to 9 can be left to the convenience of the investigator. We have found it most convenient to work a study area of $10 \mathrm{~m} \mathrm{x}$ $10 \mathrm{~m}$, although in tall Rhizophora forests and some other areas $20 \mathrm{~m}$ x $20 \mathrm{~m}$ may be more appropriate. An optimum number of 10 people make it possible to efficiently collect and record data on the major groups of fauna and flora and leave people free to fully document site details.

Items 10 to 12 are important in interpreting results of the animal collections. They describe environmental features which exert an important influence on behaviour.

Item 13 is of similar importance. The sort of information which may be conveyed here is related to tjie influences adjacent areas exert on the study site. Examples could be the pattern of freshwater flow, water pollution from a dump site, etc.

\section{VEGETATION}

Species should be recorded where possible. When this is in doubt an adequate description with specimens for later identification will be adequate. Relative abundance as used here is determined by rating the species against the least common species which is recorded as 1 . Thus an assemblage of 5 Avicennia; 11 Aegiceras, and 20 Ceriops on a 10 x 10 metre site would score the following: $1 ; 2.2$ and 4 respectively.

Spatial distribution is a visually assessed measure of pattern. Each species is treated separately and then compared in relation to inter-species distances. This will provide an indication of the spatial patterning of each species.

Average heights of each species and average heights to the lowest foliage are recorded in metres. Facility is available for size of the tree to be recorded either as basal diameter or as d.b.h. Diameter at breast height (d.b.h.) may not always be a suitable parameter. This is often the case with shrubs of Aegiceras or large individuals of Rhizophora, for example.

Flowering and fruiting (items 16 and 17) are determined for each species of mangrove and ground vegetation after examining a number of individuals (desirably $>10$ ). From this data proportions are calculated ac- 
cording to the table in the pro forma. Finally indicate whether the flowering individuals are coming into flower (fruit); are in flower (fruit); or going out of flower (fruit).

Canopy cover (item 18) is determined for mangrove and ground vegetation in the following way. Treat the stand as a whole, imagining the sun directly overhead. Indicate whether the shadows cast would be even, mottled or patchy. Indicate the density of shadows expected.

To record abundance of pneumatophores (item 19) examine the site and estimate average number per square metre. Record also their average height and average thickness at base in centimetres.

Litter (item 20) is still being determined on the basis of numerical abundance per square metre. Further work in tropical forests, particularly in the upper intertidal under Ceriops stands, may warrant collection and biomass estimates. After examining the site estimate the number per square metre of:

(a) fallen fruit; (b) fallen leaves; (c) fallen twigs and branches; (d) comment on the abundance of other litter such as logs, bottles or other structural components.

\section{ANIMALS}

For crab holes estimate numerical abundance per square metre for the hole diameters listed in the table. For biting insects choose the term from the table you find most appropriate as an abundance estimate.

SOIL

Examine a soil profile as carefully as possible so as to avoid disturbance of horizons. Our profiles have been taken to a depth of $24 \mathrm{~cm}$. Describe the horizons noting their depth, colour, soil texture and the presence of fibrous material. Soil texture can be classified qualitatively on a 7 point scale through mud to sand and clay. Note in addition to this any other features of interest such as presence of algal material on the surface; or the presence of a hydrogen sulphide odour. 
Field Sheet A

\section{MACROHABITAT DESCRIPTION}

Pro forma for recording physiognomic/biological/structural features of field study sites. (Details for the interpretation of headings and the coding of information are contained in the accompanying Explanatory Notes.)

\section{SITE IDENTIFICATION}

1. Geographic Locality:

2. Date:

3. Site Code:

4. Location of Sampling Site: 5. Size of Site:

6. Time of Observations: 7. No. of Personnel:

8. Tide Times: L.W to. L.W.

9. Tide Heights: L.W H.W. L.W.

10. Inundation : (a) all high tides H.W tides only

(b) within past 24 hours

(c) middle tide rising low tide rising middle tide falling

11. Wind: (a) direction low tide falling

12. Rain : (a) raining at present (b) strength past 24 hours

(c) significant rain in past $24-72$ hours

(d) no significant rain in past 72 hours.

13. Site in relation to adjacent ecological features :

(a) immediately adjacent areas

LHS (facing high intertidal):

RHS:

High intertidal:

Low intertidal:

(b) Other neighbouring areas 
E.J. HEGERL \& J.D.S. DAVIE

VEGETATION

14. Trees :

\begin{tabular}{|l|l|l|l|l|l|l|}
\hline Species & Rel. abundance & $\begin{array}{l}\text { Spatial } \\
\text { distrib. }\end{array}$ & $\begin{array}{c}\text { Ave. crown } \\
\text { height }\end{array}$ & $\begin{array}{c}\text { Ave. height to } \\
\text { lowest foliage }\end{array}$ & $\begin{array}{c}\text { Ave. basal } \\
\text { diameter }\end{array}$ & Ave. d.b.h. \\
\hline & & & & & & \\
& & & & & & \\
\hline
\end{tabular}

15. Ground Vegetation :

(shrubs and herbs)

\begin{tabular}{|l|l|l|l|l|l|}
\hline Species & $\begin{array}{c}\text { Relative } \\
\text { abundance }\end{array}$ & $\begin{array}{c}\text { Spatial } \\
\text { distrib. }\end{array}$ & Ave. height & $\begin{array}{c}\text { Ave. height to } \\
\text { lowest foliage }\end{array}$ & $\begin{array}{c}\text { Ave. basal } \\
\text { diameter }\end{array}$ \\
\hline & & & & & \\
\end{tabular}

\section{Flowering}

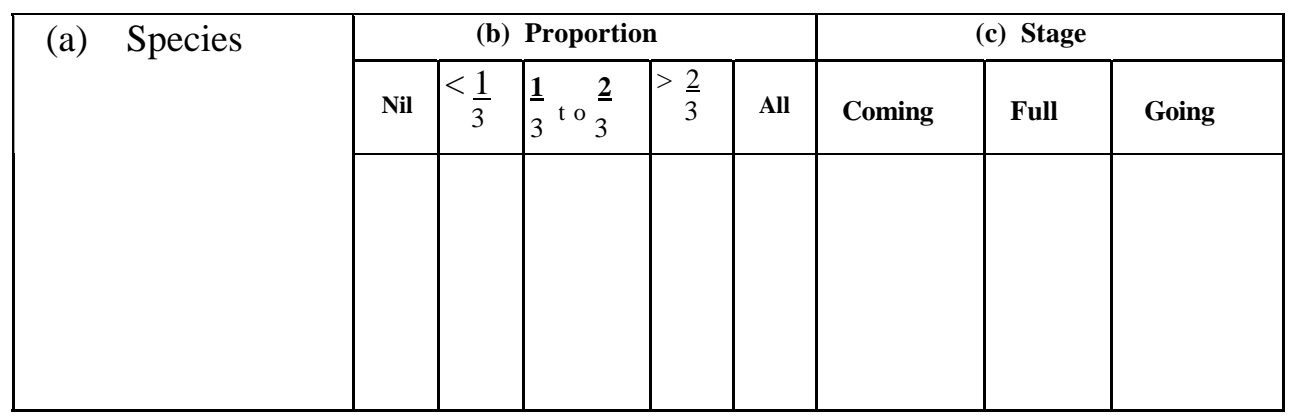

42 
THE MANGROVE FORESTS OF CAIRNS

17. Fruiting

\begin{tabular}{|c|c|c|c|c|c|c|c|c|}
\hline \multirow[t]{6}{*}{ (a) Species } & \multicolumn{5}{|c|}{ (b) Proportion } & \multicolumn{3}{|c|}{ (c) Stage } \\
\hline & Nil & $<\frac{1}{3}$ & $\frac{1}{3}$ to $\frac{2}{3}$ & $>\frac{2}{3}$ & All & Coming & Full & Going \\
\hline & & & & & & & & \\
\hline & & & & & & & & \\
\hline & & & & & & & & \\
\hline & & & & & & & & \\
\hline
\end{tabular}

18. Canopy Cover :

\begin{tabular}{|c|c|c|c|c|c|}
\hline (a) Propo & (b) Patt & (c) Density & (a) Propo & (b) Patt & (c) Density \\
\hline $\begin{array}{c}<\frac{1}{3} \\
\frac{1}{3} \text { to } \frac{2}{3} \\
>\frac{2}{3}\end{array}$ & $\begin{array}{l}\text { even } \\
\text { mottled } \\
\text { patchy }\end{array}$ & $\begin{array}{l}\text { dense } \\
\text { intermediate } \\
\text { sparse }\end{array}$ & $\begin{array}{c}<\frac{1}{3} \\
\frac{1}{3} \text { to } \frac{2}{3} \\
>\frac{2}{3}\end{array}$ & $\begin{array}{l}\text { even } \\
\text { mottled } \\
\text { sparse }\end{array}$ & $\begin{array}{l}\text { dense } \\
\text { intermediate } \\
\text { sparse }\end{array}$ \\
\hline
\end{tabular}

19. Pneumatophores :
(a) Abundance.
(b) Ave. height
(c) Ave. diam
(d) Other details

20. Litter :

Abundance :
(a) Fruit
(b) Leaves
(c) Twigs \& small branches
(d) Other details 


\section{ANIMALS}

21. Crab Holes :

(a) Estimated abundance for holes with entrance diameter

\begin{tabular}{|l|l|l|l|}
\cline { 2 - 4 } \multicolumn{1}{c|}{} & $0-10$ & $10-100$ & $>100$ \\
\hline$<0.5 \mathrm{~cm}$ & & & \\
$0.5-1.5 \mathrm{~cm}$ & & & \\
$>1.5 \mathrm{~cm}$ & & & \\
\hline
\end{tabular}

22. Biting Insects :

\begin{tabular}{|l|l|l|l|l|l|}
\cline { 2 - 6 } \multicolumn{1}{c|}{} & None & Few & Moderate & Many & Very abundant \\
\hline Biting midges & & & & & \\
Mosquitoes & & & & & \\
\hline
\end{tabular}

23. Hydrogen Sulphide Odour :

Not noticeable. Slight

24. Details of Profile :

(diagram separately)

\begin{tabular}{|l|l|l|l|l|l|}
\hline Horizon & Depth & Colour & Texture & Fibrous material & Notes \\
\hline A & & & & & \\
B & & & & & \\
C & & & & & \\
\hline
\end{tabular}

25. Other Notes :

\section{Field Sheet B}

Note: This field sheet contains information on the specific habitats of the species as they are collected within the study site. Some typical microhabitat details have been included as examples below. These data were collected from the Cairns area. The column on the right 
allows a measure of the pattern of spatial distribution of the species. This is crudely obtained by estimating the number of individuals occurring in the $10 \mathrm{~m} \times 10 \mathrm{~m}$ study site and dividing by the number of individuals occurring within a square metre quadrat chosen visually to be the most dense on the site.

\section{Field Sheet B}

\section{MICROHABITAT DESCRIPTION}

Locality southern tip Admiralty Is., Trinity Inlet Site Code No.

Date..... Dec. 12. 1974

\begin{tabular}{|l|l|c|}
\hline $\begin{array}{l}\text { Species } \\
\text { (or species description) }\end{array}$ & Microhabitat & Distribution pattern \\
\hline Nerita lineata & $\begin{array}{l}\text { On Rhizophora prop roots } \\
\text { up to } 2.5 \text { m above substrate }\end{array}$ & $20 / 5$ \\
\hline Barbatia sp. & inside rotted log & $15 / 3$ \\
\hline Assiminea relata ? & inside rotted log & $10 / 5$ \\
\hline Saccostrea cucculata & on prop roots up to $1 \mathrm{~m}$ & $100 / 20$ \\
& above substrate & \\
\hline
\end{tabular}


APPENDIX B

\title{
SPECIES LISTS
}

\section{MANGROVES}

F. Caesalpiniaceae

Cynometra ramiflora

F. Euphorbiaceae

Excoecaria agallocha

F. Meliaceae

F. Sterculiaceae

F. Myrtaceae

F. Sonneratiaceae

F. Rhizophoraceae
F. Combretaceae
F. Myrsinaceae
F. Plumbaginaceae
F. Rubiaceae
F. Verbenaceae
F. Acanthaceae

Xylocarpus australasicum

Xylocarpus granatum

Heritiera littoralis

Osbornia octodonta

Sonneratia alba

Bruguiera exaristata

Bruguiera gymnorhiza

Bruguiera parviflora

Ceriops decandra

Ceriops tagal

Rhizophora apiculata

Rhizophora stylosa

Lumnitzera littoralis

Lumnitzera racemosa

Aegiceras corniculatum

Aegialitis annulata

Scyphiphora hydrophyllacea

Avicennia marina

Acanthus ilicifolius

\section{MANGROVE EPIPHYTES}

\section{FUNGI}

Basidiomycetes

F. Thelephoraceae

F. Polyporaceae

\author{
Stereum lamellatum \\ Ganoderma ochrolaccatum \\ Ganoderma williamsianum \\ Osmoporus carteri \\ Osmoporus floccosus forma \\ Osmoporus sp. \\ Phellinus badius \\ Phellinus caliginosus \\ Phellinus gilvus \\ Phellinus spadiceus \\ Pseudoflavolus polygrammus
}


THE MANGROVE FORESTS OF CAIRNS

\section{FUNGI (contd.)}

F. Polyporaceae

Trametes hirsuta

Trametes mulleri

Tyromyces grammocephalus

\section{LICHENS}

F. Lecanoraceae

Lecanora cf. pallida

F. Collemataceae

Leptogium sp.

F. Pertusariaceae

Ochrolechia sp.

F. Pannariaceae

Pannaria lurida

F. Parmeliaceae

Pannaria sp.

Parmelia dilatata

Parmelia perlata

Parmelia cf. rudecta

F. Physciaceae

Physcia sp.

Ramalina cf. intermedia

1 unident. sp.

3 unident. spp.

Families undetermined

\section{PTERIDOPHYTA}

F. Polynodiaceae

Platycerium sp.

Polypodium confluens

Pnlypodium rigidulum

MAGNOLIAPHYTA

\section{MAGNOLIATAE}

F. Asclepiadaceae

F. Rubiaceae

\section{Dischidia nummularia}

Myrmecodia beccarii

(inhabited by ants of the Genus Pheidole)

\section{LILIATAE}

F. Orchidaceae

Cymbidium madidium var leroyi

Dendrobium discolor var discolor forma broomfieldii 
LILIATAE (contd.)

Dendrobium discolor var discolor forma discolor

Dendrobium rigidum

Dendrobium teretifolium var fasciculatum

\section{ASSOCIATED WETLAND FLORA}

PTERIDOPHYTA

F. Pteridacfcae

Acrostichum speciosum

MAGNOLIAPHYTA

MAGNOLIATAE

F. Chenopodiaceae

Arthrocnemum sp.

Pachycornia tenuis

Salicornia sp.

Sueada australis

Blm diperbaiki

F. Portulacaceae

T Tecticornia australasica

?????????????????

Portulaca australis

F. Aizoaceae

Sesuvium portulacastrum

F. Fabaceae

F. Malvaceae

Canavalia maritima

Hibiscus tiliaceus

Thespesia populnea

LILIATAE

F. Amaryllidaceae

Crinum pedunculatum

F. Restionaceae

F. Poaceae

Leptocarpus sp.

Paspalum sp.

Sporobolus virginicus

F. Pandanaceae

Pandanus sp.

F. Cyperaceae

Eleocharis sp.

Fimbristylis ferruginea

Fimbristylis polytrichoides 


\section{MOLLUSCA}

\section{CLASS GASTROPODA}

F. Assimineidae

F. Cerithiidae

F. Hydrobiidae

F. Littorinidae

F. Muricidae

F. Nassariidae

F. Neritidae

F. Potamididae

F. Aplysiidae

F. Onchidiidae

F. Atyidae

F. Ellobiidae
Assiminea relata?

Cerithium cf. tenellum

Posticobia sp.

Littorina scabra

1 unident. sp.

Nassarius olivaceus

Neritina oualaniensis

Nerita lineata

Nerita planospira

Neritina crepidularia

Cerithidea cingulata

Cerithidea largillierti

Cerithidea obtusa

Telescopium telescopium

Terebralia sulcata

Aplysia sp.

5 unident. spp.

Haminoea sp.

Cassidula angulifera

Cassidula cf. bilabiata

Cassidula doliolum

Cassidula rugata

Cassidula sowerbyana

Ellobium aurisjudae

Ellobium sp.

cf. Ellobium sp.

Melampus striatus

Melampus (2 spp.)

Ophicardelus sulcatus

Pythia scarabaeus

CLASS BIVALVIA

Enigmonia aenigmatica

Barbatia sp. 
E.J. HEGERL \& J.D.S. DAVIE

MOLLUSCA (contd.)

CLASS BIVALVIA (contd.)

F. Geloinidae

F. Isognomontidae

F. Laternulidae

F. Lucinidae?

F. Mactridae

F. Mytilidae

F. Ostreidae

F. Pholadidae

P. Teredidae

F. Veneridae

F. ?

F. Loliginidae

F. Ampithoidae

F. Gammaridae

F. Hyalellidae

F. Talitridae

F. Callianassidae

F. Paguridae

F. Porcellanidae

\section{Geloina coaxans}

Isognomon ephippium

Latemula creccina

cf. Austriella sp.

Zenatiopsis sp.

cf. Amygdalum sp.

Trichomya sp.

1 unident sp.

Ostrea sp.

Saccostrea cuccullata

Martesia striata

Bactronophorus sp.

1 unident. sp.

3 unident. spp.

CLASS CEPHALOPODA

cf. Loligo sp.

ARTHROPODA

CLASS CRUSTACEA

ORDER AMPHIPODA

Cymadusa sp.

Eriopisa sp.

Hyalella sp.

Orchestia sp.

ORDER DECAPODA

Callianassa australiensis

Clibanarius sp.

Pachycheles sp.

Petrolisthes teres

Petrolisthes sp. 
THE MANGROVE FORESTS OF CAIRNS

ARTHROPODA (contd.)

ORDER DECAPODA (contd.)

F. Grapsidae

Ilyograpsus paludicolor

Metopograpsus frontalis

Metopograpsus latifrons

Clistocoeloma merguiense

Helograpsus haswellianus

Nanosesarma minutum

Sarmatium crassum

Sesarma borneensis

Sesarma brevicristatum

Sesarma edwardsi

Sesarma cf. elongata

Sesarma gemmifera

Sesarma indica

Sesarma leptosoma

Sesarma meinerti

Sesarma messa

Sesarma moluccensis

Sesarma semperi longicristatum

F. Hymenosomidae

Sesarma smithi

Halicarcinus sp.

F. Ocypodidae

Rhyncoplax sp.

Australoplax tridentata

Cleistostoma wardi

Leipocten sordidulum

Macrophthalmus cf. crinitus

Macrophthalmus latreillei

Macrophthalmus pacificus

Paracleistostoma meneilli

Uca arcuatus

Uca coarctatus

Uca lacteus

Uca signatus

Uca vocans

Uca dussumieri

Uca sp. 
E.J. HEGERL \& J.D.S. DAVIE

ARTHROPODA (contd.)

ORDER DECAPODA (contd.)

F. Portunidae

Ilyoplax dentata

Ilyoplax orientalis

Portunus sp.

Scylla serrata

Thalamita crenata

Thalamita crenata

1 unident. sp.

F. Xanthidae

Epixanthus dentatus

Eurycarcinus maculata

Leptodius exaratus

Myomenippe fornasinii

? Rhizopa sasekumari

F. Alpheidae

Alpheus (2 spp.)

Athanus sp.

F. Atyidae

F. Palaemonidae

Caridina gracilirostris

Leander sp.

Macrobrachium cf. australiense

Macrobrachium nouae-hollandiae

Macrobrachium tolmerum

F. Penaeidae

Metapenaeopsis novae-guinea

Metapenaeus sp.

Penaeus merguiensis

F. Squillidae

Chlorida sp.

ORDER ISOPODA

F. Sphaeromatidae

Exosphaeroma allata

Sphaeroma terebrans

Sphaeroma sp.

F. Eurydicidae

Cirolana sp.

\section{ORDER OPERCULATA}

F. Balanidae

Balanus amphitrite

Elminius (2 spp.) 


\section{ORDER PEDUNCULATA}

F. Pentaspidae

Dischelaspis sp.

\section{CLASS INSECTA}

\section{ORDER BLATTODEA}

F.

F. Blattellidae

Balta sp.

1 unident. sp.

Blattidae

Platyzosteria nitida

\section{ORDER ORTHOPTERA}
F. Acrididae
F. Gryllidae
F. Rhaphidophoridae

Austracris guttulosa

1 unident. sp.

1 unident. sp.

\section{ORDER HEMIPTERA}

$\begin{array}{ll}\text { F. } & \text { Lygadidae } \\ \text { F. } & \text { Aradidae } \\ \text { F. } & \text { Reduviidae } \\ \text { F. } & \text { Veliidae }\end{array}$

F. Carabidae

F. Chrysomelidae

F. Scarabaeidae

F. Ceratopogonida

F. Coelopidae
1 unident. sp.

Neuroctenus sp. 1

unident. sp.

Holovelia sp.

\section{ORDER COLEOPTERA}

1 unident. sp.

Calomela sp.

Monolepta australis

Rhypadia sp.

Eupoecilia australasiae

\section{ORDER DIPTERA}

Culicoides molestus

Culicoides ornatus 1

1 unident. sp.

1 unident. sp. 
EJ. HEgerL \& J.D.S. DAVIE

INSECTA (contd.)

ORDER DIPTERA (contd.)

F. Culicidae

F. Lauxanidae

F. Sarcophagidae

F. Tabanidae

F. Formicidae

F. Amaurobiidae

F. Argiopidae

F. Clubionidae

F. Drassidae

54
Aedes vigilax

Aedes (Verrallina) sp.

Culex sitiens

1 unident. sp.

Parasarcophaga sp.

Tabanus sp.

ORDER HYMENOPTERA

Camponotus sp.

Oecophylla smaragdina

Pheidole sp.

Polyrachis (2 spp.)

CLASS ARACHNIDA

Phryganoporus sp.

1 unident. sp.

Anepsion sp.

Araneus poltyoides

Araneus cf. transmarrinus

Araneus sp.

Cyclosa sp.

Cyrtophora hirta

Cyrtophora moluccensis

Gasteracantha fornicata

Leucauge sp.

Nephila maculata

Nephilengys malabarensis

Phonognatha graeffei

Phonognatha sp.

Tetragnatha sp.

1 unident. sp.

Chiracanthium sp.

Lampona cylindrata 
CLASS ARACHNIDA (contd.)
F. Hersiliidae
F. Linyphiidae
F. Lycosidae

F. Oxyopidae

F. Pholcidae

F. Pisauridae

F. Salticidae

F. Sparassidae

F. Theridiidae

F. Thomosidae
Tama cf. fickerti

1 unident. sp.

Lycosa palabunda

Lycosa sp.

Storena formosa

1 unident. sp.

Oxyopes elegans

Oxyopes sp.

Pholcus sp.

Dotomedes sp.

1 unident. sp.

Cosmophasis micans

Mopsus penicillatus

Servea sp.

1 unident. sp.

Isopoda sp.

Argyrodes incisifrons

Theridion sp.

1 unident. sp.

Amyciaea albomaculata

Diaea sp.

Hedana valida

Sidymella rubrosignata

\section{CHORDATA}

\section{CLASS PISCES}
F. Elopidae
Elops australis
F. Dorosomidae
Stolephorus carpentariae
F. Belonidae
Strongylura strongylura
Tylosurus sp.
F. Hemiramphidae
Hemirhamphus (?) sp.
Rhynchorhamphus georgi
F. Syngnathidae
F. Pseudomugilidae
Pseudomugil gertrudae 
PISCES (contd.)

F. Mugilidae

F. Sphraenidae

F. Carangidae

F. Leiognathidae

F. Latidae

F. Chandidae

F. Serranidae

F. Lutjanidae

F. Pomadasyidae

F. Sparidae

F. Gerridae

F. Sillaginidae

F. Monodactylidae

F. Toxotidae

F. Scatophagidae

F. Blennidae

F. Siganidae

F. Periophthalmidae

F. Gobiidae

F. Cyprinodontidae

F. Eleotridae

\section{Liza argentea}

Liza diadema

Crenimugil labiosus

Agrioposphraena barracuda

Caranx ignobilis

Caranx sexfasciatus

Chorinemus tolooparah

Pentalabus parasiticus

Equula equula

Equulites moretoniensis

Lates calcarifer

Priopidichthys dussumieri

Ambassis nalua

Ambassis pallidus

Epinephelus australis

Epinephelus merra

Lutjanus argentimaculatus

Lutjanus sp.

Pomadasys hasta

Pomadasys opercularis

Acanthopagrus berda

Gerres filamentosus

Gerres sp.

Sillago sihama

Monodactylus argenteus

Toxotes chatareus

Scatophagus argus

Omobranchus sp.

Siganus guttatus

Siganus spinus

Periophthalmus koeIreuteri

Periophthalmus sp.

Paragobion sp.

Ctenogobius leftwichii

1 unident. sp.

Gambusia affinis

Parioglossus rainfordi

2 unident. spp. 
THE MANGROVE FORESTS OF CAIRNS

"PISCES (contd.)

F. Platycephalidae

F. Lagocephalidae

F. Bothidae

F. Tetrodontidae

F. Triacanthidae

Platycephalus sp.

Takifuga oblongus

Pseudorhombus arsius

Arothron immaculatus

Triacanthus biaculeatus

CLASS REPTILIA

ORDER CROCODILIA

F. Crocodylidae

Crocodylus porosus

ORDER SQUAMATA

F. Gekkonidae

Gehyra variegata

F. Scincidae

Carlia fusca 